\title{
Review article: Hydrological modeling in glacierized catchments of central Asia - status and challenges
}

\author{
Yaning Chen, Weihong Li, Gonghuan Fang, and Zhi Li \\ State Key Laboratory of Desert and Oasis Ecology, Xinjiang Institute of Ecology and Geography, \\ Chinese Academy of Sciences, Urumqi 830011, China \\ Correspondence to: Yaning Chen (chenyn@ms.xjb.ac.cn)
}

Received: 27 June 2016 - Published in Hydrol. Earth Syst. Sci. Discuss.: 25 July 2016

Revised: 17 December 2016 - Accepted: 22 December 2016 - Published: 2 February 2017

\begin{abstract}
Meltwater from glacierized catchments is one of the most important water supplies in central Asia. Therefore, the effects of climate change on glaciers and snow cover will have increasingly significant consequences for runoff. Hydrological modeling has become an indispensable research approach to water resources management in large glacierized river basins, but there is a lack of focus in the modeling of glacial discharge. This paper reviews the status of hydrological modeling in glacierized catchments of central Asia, discussing the limitations of the available models and extrapolating these to future challenges and directions. After reviewing recent efforts, we conclude that the main sources of uncertainty in assessing the regional hydrological impacts of climate change are the unreliable and incomplete data sets and the lack of understanding of the hydrological regimes of glacierized catchments of central Asia. Runoff trends indicate a complex response to changes in climate. For future variation of water resources, it is essential to quantify the responses of hydrologic processes to both climate change and shrinking glaciers in glacierized catchments, and scientific focus should be on reducing uncertainties linked to these processes.
\end{abstract}

\section{Introduction}

Climate change is widely anticipated to exacerbate water stress in central Asia in the near future (Siegfried et al., 2012), as the vast majority of the arid lowlands in the region are highly dependent on glacier meltwater supplied by the Tienshan Mountains, which are known as the "water tower" of central Asia (Hagg et al., 2007; Sorg et al., 2012; Lutz et al., 2014). In fact, in the alpine river basins of the northern Tienshans, glacier meltwater contributes $10 \%$ of annual runoff and $20 \%$ of runoff during the drought years (Aizen et al., 1997); therefore, climate-driven changes in glacier/snowfed runoff regimes have significant effects on water supplies (Immerzeel et al., 2010; Kaser et al., 2010).

According to a study conducted by the Eurasian Development Bank, changes in temperature and precipitation in central Asia have led to rapid regression in glaciers (Ibatullin et al., 2009). The overall decrease in total glacier area and mass from 1961 to 2012 to be $18 \pm 6 \%$ and $27 \pm 15 \%$, respectively. These values correspond to a total area loss of $2960 \pm 1030 \mathrm{~km}^{2}$, and an average glacier mass change rate of $-5.4 \pm 2.8 \mathrm{Gt} \mathrm{yr}^{-1}$ (Farinotti et al., 2015). If the warming projections developed by the Intergovernmental Panel on Climate Change (IPCC) prove to be true, the glacierized river systems in central Asia will undergo unfavorable hydrological changes, e.g., altered seasonality, increased flood risk, higher and intense spring discharge and water deficiency, in hot and dry summer periods, especially given the sharp rise in water demand (Hagg et al., 2006; Siegfried et al., 2012). The development of hydrological models on accounting for changes in current and future runoff is therefore crucial for water resources allocation in river basins, and includes understanding climatic variability as well as the impact of human activities on climate (Bierkens, 2015).

Hydrological modeling is an indispensable approach to water resources research and management in large river basins. Such models help researchers understand past and current changes and provide a way to explore the implications of management decisions and imposed changes. The purpose of hydrological modeling on basin scale is primarily 
to support decision-making for water resources management, which can be summarized as resource assessment, vulnerability assessment, impact assessment, flood risk assessment, prediction and early warning (World Meteorological Organization, 2009). It is important to choose the most suitable hydrological model for a particular watershed based on the area's climate, hydrology and underlying surface conditions.

The Tienshan Mountains span several countries and subregions, creating a decentralized political entity of complex multi-national and multi-ethnic forms. There are three large transboundary international rivers that originate in the high mountains of central Asia. In an international river, hydrological changes are related to the interests of the abutting riparian countries (Starodubtsev and Truskavetskiy, 2011; Xie et al., 2011; Guo et al., 2015). However, as conflicts between political states may arise for any number of reasons (political, cultural, etc.), transboundary issues may result in fragmented research and thus limit the development of hydrological modeling.

Amid this potential hindrance to robust research efforts, the effect of climate change on glaciers, permafrost and snow cover is having increasing impacts on runoff in glacierized central Asian catchments. However, solid water is seldom explicitly considered within hydrological models due to the lack of complete glacier data. Our knowledge of snow/glacier changes and their responses to climate forcing is still mostly incomplete. Analysis of current and future water resources variations in central Asia may promote adaptation strategies to alleviate the negative impacts of expected increased variability in runoff changes resulting from climate change.

In this paper, we review hydrological modeling efforts in five major river basins originating from the Tienshan Mountains in central Asia, namely, the Tarim River basin, the watersheds in the northern slope of the Tienshan Mountains (which includes several small river basins), the Issyk Lake basin, the Ili River basin, and the Amu Darya and Syr Darya basins (Fig. 1). Their topographical characteristics, climate and vegetation together with the glacierized area are listed in Table 1. We examine the types, purpose and use of existing models and assess the constraints and gaps in knowledge. The current lack of understanding of high-altitude hydrological regimes is causing uncertainty in assessing the regional hydrological impacts of climate change (Miller et al., 2012). Snow and glacial melt as supplies of solid water is a key element in streamflow regimes (Lutz et al., 2014); therefore, it is necessary to include glacier mass balance estimates in the model calibration procedure (Schaefli et al., 2005; Stahl et al., 2008; Konz and Seibert, 2010; Mayr et al., 2013).

\section{Modeling hydrological responses to climate change}

Changes in the amount and seasonal distribution of river runoff may have severe implications for water resources management in central Asia. "Glacier runoff" is defined as the total runoff generated from the melting of glaciers (snow and glacier), but can also include liquid precipitation on glacierized areas (Unger-Shayesteh et al., 2013). A large number of hydrological models applied in glacierized catchments of central Asia are basin-scale models, which contain empirical hydrological models as well as physical hydrological models (Table 2). These glacio-hydrological models are useful tools for anticipating and evaluating the impacts of climate changes in the headwater catchments of the main Asian rivers (Miller et al., 2012).

\subsection{Current and future runoff changes}

River runoff responds in a complex way to variations in climate and the cryosphere. At the same time, runoff changes also depend on dominant runoff components. Table 2 shows that annual runoff anomalies have increased to some extent (except in the western Tienshan Mountains) and inconsistencies between changes in precipitation and runoff have occurred in heavily glacierized catchments. In rivers fed by snow and glaciers, runoff has increased (e.g., in northern Tienshan Mountains) and rising temperatures dominate the runoff changes by, for instance, increasing the snowmelt/glacier melt and decreasing snowfall fraction (ratio of solid precipitation to liquid precipitation) (Chen, 2014). Khan and Holko (2009) compared runoff changes with variations in snow cover area and snow depth. They suggested that the mismatch between decreasing trends in snow indicators and the increasing river runoff could be the result of enhanced glacier melting. Heavily glacierized river basins showed mainly positive runoff trends in the past few decades (simulated under different scenarios in the head rivers of the Tarim River basin), while those with less or no glacierization exhibited wide variations in runoff (Duethmann et al., 2015; Kaldybayev et al., 2016).

With further warming and the resulted acceleration of glacier retreat, glacier inflection points will or have already appeared. The amount of surface water will probably decline or keep high volatility due to glacial retreat and reduced storage capacity of glaciers (Chen et al., 2015). For instance, near-future runoffs are projected to increase to some extent, with increments of 13-35\% during 2011-2050 compared to 1960-2006 for the Yarkand River, $-1-18 \%$ in the 21 st century compared to 1986-2020 under RCP4.5 for the Kaidu River, and $23 \%$ in 2020 for the Hotan River (Table 2). For the long-term, however, total runoff is projected to be smaller than today. The hydrological responses to climate change around the world were discussed in Sect. 2.3.

\subsection{Contribution of glacier melt/snowmelt water in river runoff}

Kemmerikh (1972) estimated the contribution of groundwater, snowmelt and glacier melt to the total runoff of the alpine rivers in central Asia. Based on the hydrograph separation 


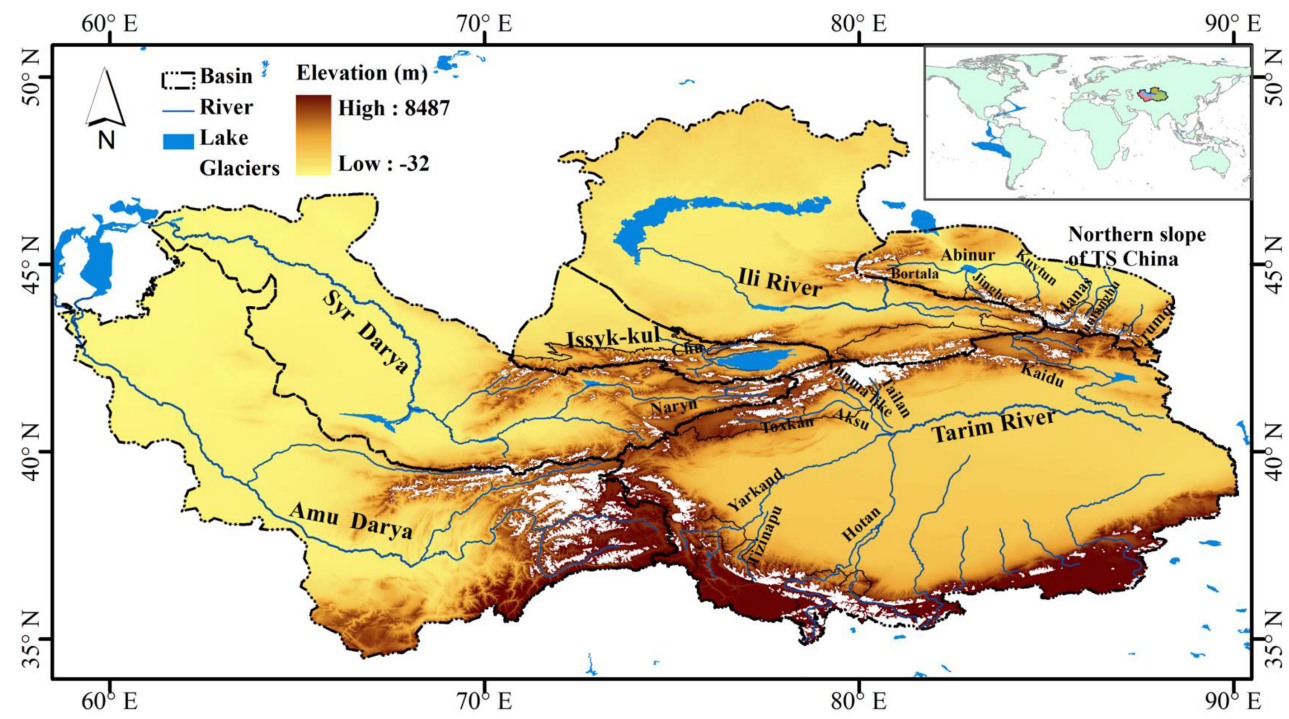

Figure 1. Map of central Asian headwaters with main river basins or hydrological regions, namely, the Tarim River basin, the watersheds in the northern slope of the Tienshan Mountains, the Issyk Lake basin, the Ili River basin, and the Amu Darya and the Syr Darya basins. Lake outlines are from Natural Earth (http://www.naturalearthdata.com/). The river system is derived based on elevations of the SRTM (Shuttle Radar Topography Mission) $90 \mathrm{~m}$ data. Glacier information was obtained from RGI (Randolph Glacier Inventory).

Table 1. Summary of climatic and underlying conditions of the basins. The topography is based on SRTM data, glacier data are from RGI (Randolph Glacier Inventory) and climate is based on the world map of the Köppen-Geiger climate classification. Vegetation is from the land use data from Xinjiang institute of Ecology and Geography.

\begin{tabular}{|c|c|c|c|c|c|c|}
\hline Catchment & $\begin{array}{l}\text { Tarim } \\
\text { River } \\
\text { basin }\end{array}$ & $\begin{array}{c}\text { Catchments } \\
\text { in northern } \\
\text { Tienshan Mountains, } \\
\text { China }\end{array}$ & $\begin{array}{l}\text { Issyk } \\
\text { Lake } \\
\text { basin }\end{array}$ & $\begin{array}{l}\text { Ili } \\
\text { River } \\
\text { basin }\end{array}$ & $\begin{array}{l}\text { Amu } \\
\text { Darya } \\
\text { Basin }\end{array}$ & $\begin{array}{c}\text { Syr } \\
\text { Darya } \\
\text { Basin }\end{array}$ \\
\hline Location & $\begin{array}{l}\text { Surrounded by the } \\
\text { Tienshan Mountains and } \\
\text { the Kunlun Mountains }\end{array}$ & $\begin{array}{l}\text { Northern } \\
\text { Tienshan }\end{array}$ & $\begin{array}{l}\text { Western } \\
\text { Tienshan }\end{array}$ & $\begin{array}{l}\text { Western } \\
\text { Tienshan } \\
\text { Valley }\end{array}$ & $\begin{array}{l}\text { Western } \\
\text { Tienshan and } \\
\text { Pamir }\end{array}$ & $\begin{array}{l}\text { Western } \\
\text { Tienshan }\end{array}$ \\
\hline \multicolumn{7}{|l|}{ Topography } \\
\hline $\begin{array}{l}\text { Basin area }\left(\mathrm{km}^{2}\right) \\
\text { Percentage of elevation } \\
>3000 \mathrm{~m}(\%)\end{array}$ & $\begin{array}{c}868811 \\
28.00\end{array}$ & $\begin{array}{c}126463 \\
13.80\end{array}$ & $\begin{array}{c}102396 \\
14.50\end{array}$ & $\begin{array}{c}429183 \\
4.60\end{array}$ & $\begin{array}{c}674848 \\
20.50\end{array}$ & $\begin{array}{c}442476 \\
9.50\end{array}$ \\
\hline Glaciation area $\left(\mathrm{km}^{2}\right)$ & 15789 & 1795 & 994 & 2170 & 9080 & 1850 \\
\hline \multicolumn{7}{|l|}{ Climate } \\
\hline Dominant climate & $\begin{array}{l}\text { arid } \\
\text { cold }\end{array}$ & $\begin{array}{l}\text { arid } \\
\text { cold }\end{array}$ & $\begin{array}{c}\text { arid } \\
\text { cold; } \\
\text { continental }\end{array}$ & $\begin{array}{c}\text { arid } \\
\text { cold; } \\
\text { continental }\end{array}$ & $\begin{array}{l}\text { arid } \\
\text { cold; } \\
\text { snow }\end{array}$ & $\begin{array}{l}\text { arid } \\
\text { cold }\end{array}$ \\
\hline \multicolumn{7}{|l|}{ Vegetation } \\
\hline $\begin{array}{l}\text { Forest percent }(\%) \\
\text { Pasture percent }(\%) \\
\text { Percent of water, snow, ice }(\%)\end{array}$ & $\begin{array}{c}0.7 \\
16.7 \\
5.4\end{array}$ & $\begin{array}{l}10.4 \\
14.5 \\
3.9\end{array}$ & $\begin{array}{c}6.4 \\
31.2 \\
7.8\end{array}$ & $\begin{array}{c}4.1 \\
28.6 \\
5.3\end{array}$ & $\begin{array}{c}10.9 \\
19.4 \\
5.3\end{array}$ & $\begin{array}{c}2.5 \\
17.3 \\
2.8\end{array}$ \\
\hline
\end{tabular}

methodology, the glacier melt contribution ranged between 5 and $40 \%$ in the plains and around $70 \%$ in upstream basins. The ratio of glacier melt contribution to runoff varies between 3.5 and $67.5 \%$ with a mean of $24.0 \%$ for the 24 catchments in the Tienshan Mountains based on hydrological modeling (Y. Zhang et al., 2016).

Distributed hydrological models provide a more useful tool for the investigation of changes in different runoff components. For example, the variable infiltration capacity (VIC) 
Table 2. Summary of hydrological modeling in glacierized central Asian catchments.

\begin{tabular}{|c|c|c|c|c|}
\hline Catchments & Models & Major conclusions & Innovations and limitations & References \\
\hline \multicolumn{5}{|l|}{ Tarim River } \\
\hline \multirow[t]{5}{*}{ Tarim River basin } & $\begin{array}{l}\text { Modified two-parameter } \\
\text { semi-distributed water } \\
\text { balance model }\end{array}$ & $\begin{array}{l}\text { Improved the original two-parameter monthly water bal- } \\
\text { ance model by incorporating the topographic indexes and } \\
\text { could get comparable results to the TOPMODEL model and } \\
\text { Xinanjiang model. }\end{array}$ & \multirow[t]{3}{*}{$\begin{array}{l}\text { Less input data are required; Lack of } \\
\text { glacier and snowmelt processes. }\end{array}$} & \multirow[t]{3}{*}{$\begin{array}{l}\text { Peng and Xu (2010); } \\
\text { Chen et al. (2006) }\end{array}$} \\
\hline & TOPMODEL model & $\begin{array}{l}\text { In the Aksu River, runoff was more closely related to pre- } \\
\text { cipitation, whereas in the Hotan River, it was more closely } \\
\text { related to temperature. }\end{array}$ & & \\
\hline & Xinanjiang model & $\begin{array}{l}\text { Runoffs of the Aksu, Yarkand and Hotan rivers exhibited } \\
\text { increasing tendencies in } 2010 \text { and } 2020 \text { under different sce- } \\
\text { narios generated from the reference years, e.g., } 23 \% \text { in- } \\
\text { crease for the Hotan River. }\end{array}$ & & \\
\hline & $\begin{array}{l}\text { PPR (Projection pursuit re- } \\
\text { gression) model }\end{array}$ & $\begin{array}{l}\text { If temperature rises } 0.5-2.0^{\circ} \mathrm{C} \text {, runoff will increase with } \\
\text { temperature for the Aksu, Yarkand and Hotan rivers. }\end{array}$ & Lack of physical basis. & Wu et al. (2003) \\
\hline & $\begin{array}{l}\text { VIC (variable infiltration ca- } \\
\text { pacity) }\end{array}$ & $\begin{array}{l}\text { For the Tarim River, runoff will decrease slightly in } 2020- \\
2025 \text { based on VIC forced by HadCM } 3 \text { under A2 and B } 2 \\
\text { when not considering glacier melt. }\end{array}$ & Lack of glacier module. & Liu et al. (2010) \\
\hline Tailan River & $\begin{array}{l}\text { Modified degree-day model } \\
\text { including potential clear sky } \\
\text { direct solar radiation cou- } \\
\text { pled with a linear reservoir } \\
\text { model }\end{array}$ & $\begin{array}{l}\text { Glacier runoff increases linearly with temperature over } \\
\text { these ranges whether or not the debris layer is taken into } \\
\text { consideration. The glacier runoff is less sensitive to temper- } \\
\text { ature change in the debris-covered area than the debris-free } \\
\text { area. }\end{array}$ & $\begin{array}{l}\text { Considered the effect of solar radiation } \\
\text { and quantified the debris effect. }\end{array}$ & Y. Zhang et al. (2007) \\
\hline \multirow{12}{*}{$\begin{array}{l}\text { Aksu River includ- } \\
\text { ing Kumalike and } \\
\text { Toxkan rivers }\end{array}$} & Xinanjiang model & $\begin{array}{l}\text { Precipitation has a weak relationship with runoff in the } \mathrm{Ku} \text { - } \\
\text { malike River. }\end{array}$ & Joined the snowmelt module. & \multirow[t]{2}{*}{ P. Wang et al. (2012) } \\
\hline & & & $\begin{array}{l}\text { The model could not well capture the } \\
\text { snowmelt-/precipitation-induced peak } \\
\text { streamflow. }\end{array}$ & \\
\hline & \multirow[t]{3}{*}{ VIC-3L model } & $\begin{array}{l}\text { Glacier melt, snowmelt and rainfall accounted for } 43.8,27.7 \\
\text { and } 28.5 \% \text { of the discharge for the Kumalike River and } \\
23.0,26.1 \text { and } 50.9 \% \text { for the Toxkan River. }\end{array}$ & \multirow[t]{3}{*}{$\begin{array}{l}\text { The model performance was obviously } \\
\text { improved through coupling a degree- } \\
\text { day glacier melt scheme, but accurately } \\
\text { estimating areal precipitation in alpine } \\
\text { regions still remains. }\end{array}$} & \multirow[t]{3}{*}{ Zhao et al. $(2013,2015)$} \\
\hline & & $\begin{array}{l}\text { For the Kumalike River and the Toxkan River, the runoff } \\
\text { has increased } 13.6 \text { and } 44.9 \% \text { during } 1970-2007 \text {, and } 94.5 \\
\text { and } 100 \% \text { of the increases were attributed by precipitation } \\
\text { increase. }\end{array}$ & & \\
\hline & & $\begin{array}{l}\text { For the Kumalike River, glacier area will reduce by }>30 \% \\
\text { resulting in decreased meltwater in summer and annual dis- } \\
\text { charge (about } 2.8-19.4 \% \text { in the } 2050 \mathrm{~s} \text { ). }\end{array}$ & & \\
\hline & \multirow[t]{3}{*}{ SWIM model } & $\begin{array}{l}\text { The model is capable to reproduce the monthly discharge at } \\
\text { the downstream gauge well, using the local irrigation infor- } \\
\text { mation and the observed upstream inflow discharges. }\end{array}$ & $\begin{array}{l}\text { Investigated the glacier lake outburst } \\
\text { floods using a modeling tool. Inclusion } \\
\text { of an irrigation module and a river trans- } \\
\text { mission losses module of the SWIM } \\
\text { model. }\end{array}$ & \multirow[t]{3}{*}{$\begin{array}{l}\text { Huang et al. (2015); } \\
\text { Wortmann et al. (2014) }\end{array}$} \\
\hline & & $\begin{array}{l}\text { About } 18 \% \text { of the incoming headwater resources consumed } \\
\text { up to the gauge in Xidaqiao, and about } 30 \% \text { additional wa- } \\
\text { ter is consumed between Xidaqiao and Alar. }\end{array}$ & $\begin{array}{l}\text { Model uncertainties are the largest in the } \\
\text { snowmelt and glacier melt periods. }\end{array}$ & \\
\hline & & $\begin{array}{l}\text { Different irrigation scenarios were developed and showed } \\
\text { that the improvement of irrigation efficiency was the most } \\
\text { effective measure for reducing irrigation water consumption } \\
\text { and increasing river discharge downstream. }\end{array}$ & & \\
\hline & \multirow[t]{2}{*}{ WASA model } & $\begin{array}{l}\text { Glacier melt contributes to } 35-48 \text { and } 9-24 \% \text { for the } \mathrm{Ku}- \\
\text { malike River and the Toxkan River. }\end{array}$ & $\begin{array}{l}\text { The model considered changes in } \\
\text { glacier geometry (e.g., glacier area and } \\
\text { surface elevation). }\end{array}$ & \multirow[t]{2}{*}{ Duethmann et al. (2015) } \\
\hline & & $\begin{array}{l}\text { For the Kumalike River, glacier geometry changes lead to } \\
\text { a reduction of } 14-23 \% \text { of streamflow increase compared to } \\
\text { constant glacier geometry. }\end{array}$ & $\begin{array}{l}\text { It used a multi-objective calibration } \\
\text { based on glacier mass balance and dis- } \\
\text { charge. }\end{array}$ & \\
\hline & $\begin{array}{l}\text { The temperature and precip- } \\
\text { itation revised } A R(p) \text { model; }\end{array}$ & \multirow[t]{2}{*}{$\begin{array}{l}\text { The AR(p) model is capable of predicting the streamflow in } \\
\text { the Aksu River basin while the NAM model is not ideal. }\end{array}$} & \multirow[t]{2}{*}{$\begin{array}{l}\text { AR(p) needs less hydrological and me- } \\
\text { teorological data. Both model fails to } \\
\text { model sudden floods such as ice dam } \\
\text { collapse floods. }\end{array}$} & \multirow[t]{2}{*}{ Ouyang et al. (2007) } \\
\hline & $\begin{array}{l}\text { NAM (NedborAfstromn- } \\
\text { ings Model) rainfall runoff } \\
\text { model }\end{array}$ & & & \\
\hline
\end{tabular}


Table 2. Continued.

\begin{tabular}{|c|c|c|c|c|}
\hline Catchments & Models & Major conclusions & Innovations and limitations & References \\
\hline \multicolumn{5}{|l|}{ Tarim River } \\
\hline \multirow[t]{6}{*}{ Kaidu River } & MIKE-SHE model & $\begin{array}{l}\text { Compared remote sensing data and station-based data in } \\
\text { simulating the hydrological processes. Remote sensing data } \\
\text { are comparable to conventional data. Remote sensing data } \\
\text { could partly overcome the lack of necessary hydrological } \\
\text { model input data in developing or remote regions. }\end{array}$ & $\begin{array}{l}\text { Missing glacier melt; Lack of observa- } \\
\text { tion to verify the meteorological condi- } \\
\text { tion in the mountainous regions. }\end{array}$ & $\begin{array}{l}\text { T. Liu et al. (2012); } \\
\text { Liu et al. (2013) }\end{array}$ \\
\hline & $\begin{array}{l}\text { HBV (Hydrologiska Byrans } \\
\text { Vattenbalansavdelning) } \\
\text { model }\end{array}$ & $\begin{array}{l}\text { When the base runoff is } 100 \mathrm{~m}^{3} \mathrm{~s}^{-1} \text {, the critical rainfall for } \\
\text { primary and secondary warning floods are } 50 \text { and } 30 \mathrm{~mm} \text {, } \\
\text { respectively, for the Kaidu River. }\end{array}$ & $\begin{array}{l}\text { It underestimated the peak streamflow } \\
\text { while overestimated the base flow. }\end{array}$ & Fan et al. (2014) \\
\hline & $\begin{array}{l}\text { SRM (snowmelt runoff } \\
\text { model) including potential } \\
\text { clear sky direct solar radia- } \\
\text { tion and the effective active } \\
\text { temperature. }\end{array}$ & $\begin{array}{l}\text { Spring streamflow is projected to increase in the future } \\
\text { based on HadCM3. }\end{array}$ & $\begin{array}{l}\text { Limited observations resulted in low } \\
\text { modeling precision. The APHRODITE } \\
\text { precipitation performed well in hydro- } \\
\text { logical modeling in the Kaidu River. }\end{array}$ & $\begin{array}{l}\text { Y. C. Zhang et al. (2007); } \\
\text { Ma et al. (2013); Li et } \\
\text { al. (2014). }\end{array}$ \\
\hline & SWAT & $\begin{array}{l}\text { Precipitation and temperature lapse rates account for } 64.0 \% \\
\text { of model uncertainty. }\end{array}$ & $\begin{array}{l}\text { Quantified uncertainty resulted from the } \\
\text { meteorological inputs. }\end{array}$ & \multirow[t]{2}{*}{ Fang et al. $(2015 a, b)$} \\
\hline & & $\begin{array}{l}\text { Runoff increases }(-1)-18 \text { and } 4-20 \% \text { in the } 21 \text { st century } \\
\text { under RCP } 4.5 \text { and RCP } 8.5 \text { compared to } 1986-2005 \text { based } \\
\text { on a cascade of regional climate model RegCM, bias cor- } \\
\text { rection and SWAT model. }\end{array}$ & & \\
\hline & $\begin{array}{l}\text { Modified system dynamics } \\
\text { model }\end{array}$ & $\begin{array}{l}\text { Simulations of low flow and normal flow are much better } \\
\text { than the high flow, and spring peak flow is better than the } \\
\text { summer pecks in the Kaidu River. }\end{array}$ & $\begin{array}{l}\text { Applied the effective cumulative tem- } \\
\text { perature to calculate snowmelt process } \\
\text { and soil temperature for each layer to } \\
\text { describe water movement in soil. }\end{array}$ & F. Y. Zhang et al. (2016) \\
\hline \multirow[t]{4}{*}{ Yarkand River } & MIKE-SHE model & $\begin{array}{l}\text { Simulated snowpack using station data differs significantly } \\
\text { from that using remote sensing data. }\end{array}$ & Lack of glacier module & Liu et al. (2016b) \\
\hline & $\begin{array}{l}\text { Integrating Wavelet Anal- } \\
\text { ysis (WA) and back- } \\
\text { propagation artificial neural } \\
\text { network (BPANN) }\end{array}$ & $\begin{array}{l}\text { Runoff presented an increasing trend similar with tempera- } \\
\text { ture and precipitation at the timescale of } 32 \text { years. But at the } \\
2-, 4-, 8-\text {, and 16-year timescale, runoff presented nonlinear } \\
\text { variation. }\end{array}$ & $\begin{array}{l}\text { Interpreted the nonlinear characteris- } \\
\text { tics of the hydro-climatic process using } \\
\text { statistic method. }\end{array}$ & Xu et al. (2014) \\
\hline & Degree-day model & $\begin{array}{l}\text { Decreasing rate of glacier mass was } 4.39 \mathrm{~mm} \mathrm{a}^{-1} \text { result- } \\
\text { ing in a runoff increasing trend of } 0.23 \times 10^{8} \mathrm{~m}^{3} \mathrm{a}^{-1} \text { dur- } \\
\text { ing } 1961-2006 \text {. Sensitivity of mass balance to temperature } \\
\text { is } 0.16 \mathrm{~mm} \mathrm{a}^{-1}{ }^{\circ} \mathrm{C}^{-1} \text {. }\end{array}$ & $\begin{array}{l}\text { The glacier dynamics is considered and } \\
\text { the area-volume scaling factor is cali- } \\
\text { brated using remote sensing data. }\end{array}$ & $\begin{array}{l}\text { Xie et al. (2006); Zhang } \\
\text { et al. }(2012 \mathrm{a}, \mathrm{b})\end{array}$ \\
\hline & & $\begin{array}{l}\text { Glacier runoff will increase } 13-35 \% \text { during } 2011-2050 \\
\text { compared to } 1960-2006 \text { with obvious increase in summer. }\end{array}$ & & \\
\hline \multirow[t]{2}{*}{ Tizinapu } & \multirow[t]{2}{*}{ SRM including snow albedo } & It could well simulate the runoff of the Tizinapu River. & \multirow[t]{2}{*}{ Lack of glacier module. } & \multirow[t]{2}{*}{ Li and Williams (2008) } \\
\hline & & $\begin{array}{l}\text { Runoff is dominated by precipitation and temperature lapse } \\
\text { rates, and snow albedo. }\end{array}$ & & \\
\hline Hotan River & $\begin{array}{l}\text { Integrating Wavelet Anal- } \\
\text { ysis (WA) and back- } \\
\text { propagation artificial neural } \\
\text { network (BPANN) }\end{array}$ & $\begin{array}{l}\text { Runoff correlates well with the } 0^{\circ} \mathrm{C} \text { level height in summer } \\
\text { for the northern slope of Kunlun Mountains. }\end{array}$ & $\begin{array}{l}\text { Interpreted the nonlinear characteristics } \\
\text { of the hydro-climatic process. }\end{array}$ & Xu et al. (2011) \\
\hline \multicolumn{5}{|c|}{ Catchments in northern slope of Tienshan Mountains, China } \\
\hline \multirow[t]{3}{*}{ Manas River } & (1) SWAT model & $\begin{array}{l}\text { Glacier area decreased by } 11 \% \text { during } 1961-1999 \text { and } \\
\text { glacier melt contributes } 25 \% \text { of discharge. }\end{array}$ & $\begin{array}{l}\text { Both the glacier melt module and two- } \\
\text { reservoir method were included in the } \\
\text { hydrological simulations. }\end{array}$ & $\begin{array}{l}\text { Yu et al. (2011); Luo } \\
\text { et al. (2012); Luo et } \\
\text { al. (2013); Gan and } \\
\text { Luo (2013) }\end{array}$ \\
\hline & (2) SRM model & $\begin{array}{l}\text { Better simulation of snowmelt runoff than rainfall-runoff } \\
\text { by the SRM. }\end{array}$ & $\begin{array}{l}\text { Snow cover calculation algorithm is } \\
\text { added to validate model performance. }\end{array}$ & Yu et al. (2013) \\
\hline & (3) EasyDHM model & EasyDHM model could reproduce the streamflow. & $\begin{array}{l}\text { The validation is based on streamflow } \\
\text { alone. }\end{array}$ & Xing et al. (2014) \\
\hline \multirow[t]{2}{*}{ Urumqi River } & $\begin{array}{l}\text { (1) Isotope hydrograph sep- } \\
\text { aration (IHS) }\end{array}$ & Glacier meltwater contributes to $9 \%$ of runoff. & $\begin{array}{l}\text { The IHS method has overwhelming po- } \\
\text { tential in analyzing hydrological com- } \\
\text { ponents for ungauged watersheds. }\end{array}$ & Kong and Pang (2012) \\
\hline & (2) Water balance model & $\begin{array}{l}\text { The cumulative mass balance of the glacier was }-13.69 \mathrm{~m} \\
\text { during } 1959-2008 \text {; proportion of glacier runoff increased } \\
\text { from } 62.8 \text { to } 72.1 \% \text {. }\end{array}$ & $\begin{array}{l}\text { Foused on runoff generation on the } \\
\text { glacierized and ablation area. }\end{array}$ & Sun et al. (2013) \\
\hline
\end{tabular}


Table 2. Continued.

\begin{tabular}{|c|c|c|c|c|}
\hline Catchments & Models & Major conclusions & Innovations and limitations & References \\
\hline \multicolumn{5}{|c|}{ Catchments in northern slope of Tienshan Mountains, China } \\
\hline & (3) HBV model & $\begin{array}{l}\text { For a glacierized catchment (glacierization ratio is } 18 \% \text { ), } \\
\text { the discharge will increase by } 66 \pm 35 \% \text { or decrease by } \\
40 \pm 13 \% \text { if the glacier size keeps unchanged or glacier dis- } \\
\text { appears in } 2041-2060 \text {. }\end{array}$ & $\begin{array}{l}\text { Considering future runoff under differ- } \\
\text { ent glacier change scenarios. }\end{array}$ & Sun et al. (2015) \\
\hline & (4) Exponential regression & $\begin{array}{l}\text { Glacier runoff is critically affected by the ground tempera- } \\
\text { ture. }\end{array}$ & $\begin{array}{l}\text { This study shed light on glacier runoff } \\
\text { estimation based on ground temperature } \\
\text { for data-scarce regions. }\end{array}$ & Chen et al. (2012) \\
\hline & (5) SRM model & $\begin{array}{l}\text { The degree day factor is not constant for different elevation } \\
\text { bands. }\end{array}$ & $\begin{array}{l}\text { Calculated the curve of snow cover } \\
\text { shrinkage based on MODIS data. }\end{array}$ & Huai et al. (2013) \\
\hline & $\begin{array}{l}\text { (6) THModel (Thermody- } \\
\text { namic Watershed Hydrolog- } \\
\text { ical Model) }\end{array}$ & $\begin{array}{l}\text { THModel can indeed simulate runoff processes in the } \\
\text { glacier and snow-dominated catchment reasonably well. }\end{array}$ & $\begin{array}{l}\text { An energy balance model is proposed to } \\
\text { close the balance equation of soil freez- } \\
\text { ing and thawing. }\end{array}$ & Mou et al. (2008) \\
\hline \multirow{2}{*}{$\begin{array}{l}\text { Ebinur Lake catch- } \\
\text { ment including } \\
\text { Jinghe River, Kuy- } \\
\text { tun River and Bor- } \\
\text { tala River }\end{array}$} & $\begin{array}{l}\text { (1) SWAT model and the se- } \\
\text { quential cluster method }\end{array}$ & $\begin{array}{l}\text { For the Jinghe River, } 85.7 \% \text { of the runoff reduction is } \\
\text { caused by human activity and } 14.3 \% \text { by climate change. }\end{array}$ & $\begin{array}{l}\text { Identified the effects of human activities } \\
\text { and climate change on runoff. }\end{array}$ & $\begin{array}{l}\text { Dong et al. (2014); } \\
\text { Yao et al. (2014) }\end{array}$ \\
\hline & $\begin{array}{l}\text { (2) Runoff CAR (Controlled } \\
\text { AutoRegressive) model }\end{array}$ & $\begin{array}{l}\text { The Jinghe River and Kuytun River exhibited a slightly in- } \\
\text { creasing trend, but an adverse trend in the Bortala River. } \\
\text { In a warm humid scenario, runoff in the Jinghe River and } \\
\text { Bortala River will increase while it will decrease in the } \\
\text { Kuytun River. }\end{array}$ & $\begin{array}{l}\text { The CAR is based on past and present } \\
\text { values without physical basis. }\end{array}$ & \\
\hline Juntanghu Basin & $\begin{array}{ll}\text { DHSVM } & \text { (Distributed Hy- } \\
\text { drology } & \text { Soil Vegetation } \\
\text { Model) } & \end{array}$ & $\begin{array}{l}\text { The coupled WRF (Weather Research and Forecasting) } \\
\text { modelling system and DHSVM model could predict } 24 \mathrm{~h} \\
\text { snowmelt runoff with relative error within } 15 \% \text {. }\end{array}$ & $\begin{array}{l}\text { MODIS snow cover and the calcu- } \\
\text { lated snow depth data are used in the } \\
\text { snowmelt runoff modeling. }\end{array}$ & Zhao et al. (2009) \\
\hline \multicolumn{5}{|l|}{ Issyk Lake Basin } \\
\hline $\begin{array}{l}\text { Small rivers around } \\
\text { the Issyk Lake }\end{array}$ & Degree-day approach & $\begin{array}{l}\text { Runoff contribution is varying in a broad range depend- } \\
\text { ing on the degree of glacierization in the particular sub- } \\
\text { catchment. All rivers showed a relative increase in annual } \\
\text { river runoff ranging between } 3.2 \text { and } 36 \% \text {. }\end{array}$ & $\begin{array}{l}\text { The glacier melt runoff fraction at the } \\
\text { catchment outlet can be considerably } \\
\text { overestimated. }\end{array}$ & Dikich and Hagg (2003) \\
\hline Chu River & $\begin{array}{l}\text { SWAT-RSG (RSG: rain, } \\
\text { snow and glacier) model }\end{array}$ & $\begin{array}{l}\text { General decrease was expected in glacier runoff }(-26.6 \\
\text { to }-1.0 \%) \text {, snowmelt }(-21.4 \text { to }+1.1 \%) \text { and streamflow } \\
(-27.7 \text { to }-6.6 \%) \text {; Peak streamflow will be put forward } \\
\text { for } 1 \text { month. }\end{array}$ & $\begin{array}{l}\text { Use the glacier dynamics and assessed } \\
\text { the model performance based on both } \\
\text { streamflow and glacier area. }\end{array}$ & Ma et al. (2015) \\
\hline \multicolumn{5}{|l|}{ Ili River basin } \\
\hline \multirow[t]{2}{*}{ Gongnaisi River } & SRM model & Runoff is sensitive to snow cover area and temperature. & \multirow[t]{2}{*}{$\begin{array}{l}\text { SRM is capable to model the snowmelt } \\
\text { runoff. }\end{array}$} & Ma and Cheng (2003) \\
\hline & & $\begin{array}{l}\text { If temperature increases } 4^{\circ} \mathrm{C} \text {, the runoff will decrease by } \\
9.7 \% \text { with snow coverage and runoff shifting forward. }\end{array}$ & & \\
\hline Tekes River & SWAT model & $\begin{array}{l}\text { Glaciers have retreated about } 22 \% \text { since } 1970 \text { s, which was } \\
\text { considerably higher than the Tienshan average }(4.7 \%) \text { and } \\
\text { China average }(11.5 \%) \text {, resulting in a decrease of propor- } \\
\text { tion of precipitation recharged runoff from } 9.8 \% \text { in } 1966- \\
1975 \text { to } 7.8 \% \text { in } 2000-2008 \text {. }\end{array}$ & $\begin{array}{l}\text { Using two land use data and two } \\
\text { Chinese glacier inventories, the model } \\
\text { could well reproduce streamflow. }\end{array}$ & Xu et al. (2015) \\
\hline \multirow[t]{2}{*}{ Ili River } & $\begin{array}{lr}\text { DTVGM } & \text { (multi-spatial } \\
\text { data-based } & \text { Distributed } \\
\text { Time-Variant } & \text { Gain Model) } \\
\text { model } & \end{array}$ & $\begin{array}{l}\text { Daily runoff correlated closely with snowmelt, suggesting } \\
\text { a snowmelt module is indispensable. }\end{array}$ & $\begin{array}{l}\text { This method has less dependence on } \\
\text { conventional observation. }\end{array}$ & Cai et al. (2014) \\
\hline & Water balance model & $\begin{array}{l}\text { Water decrease in } 1911-1986 \text { in the middle and lower } \\
\text { reaches of the Lake Balkhash is due to decreased rainfall } \\
\text { and reservoirs storage. }\end{array}$ & - & $\begin{array}{l}\text { Kezer and Matsuyama } \\
\text { (2006); Guo et al. (2011) }\end{array}$ \\
\hline \multicolumn{5}{|c|}{ Amu Darya and Syr Darya basins } \\
\hline \multirow[t]{2}{*}{$\begin{array}{l}\text { Amu Darya and Syr } \\
\text { Darya }\end{array}$} & STREAM & $\begin{array}{l}\text { The runoff of the Syr Darya declined considerably over the } \\
\text { last } 9000 \text { years, but show much smaller responses to future } \\
\text { warming. }\end{array}$ & $\begin{array}{l}\text { Simulated long-term discharge for the } \\
\text { Holocene and future period. }\end{array}$ & Aerts et al. (2006) \\
\hline & & $\begin{array}{l}\text { For the Amu Darya and Syr Darya basins, the glacier- } \\
\text { covered areas have decrease } 15 \text { and } 22 \% \text { in } 2001-2010 \\
\text { compared to the baseline (1960-1990). } \\
\text { For the Amu River Basin, } 20-25 \% \text { of the glaciers will re- } \\
\text { tain under a temperature increment being } 4-5^{\circ} \mathrm{C} \text { and pre- } \\
\text { cipitation increase rate being } 3 \% /{ }^{\circ} \mathrm{C} \text {. } \\
\text { For the Syr Darya, runoff under the A2 and B2 scenarios } \\
\text { will increase } 3-8 \% \text { in } 2010-2039 \text {, with sharpened spring } \\
\text { peak and a slight lowered runoff from late June to August. }\end{array}$ & $\begin{array}{l}\text { The model includes the calculation of } \\
\text { rainwater, snowmelt water and glacier } \\
\text { runoff (based on the glacier altitude and } \\
\text { equilibrium lime altitude). }\end{array}$ & $\begin{array}{l}\text { Savoskul et al. (2003); } \\
\text { Savoskul et al. (2004); } \\
\text { Savoskul and Smakhtin } \\
\text { (2013) }\end{array}$ \\
\hline
\end{tabular}


Table 2. Continued.

\begin{tabular}{|c|c|c|c|c|}
\hline Catchments & Models & Major conclusions & Innovations and limitations & References \\
\hline \multicolumn{5}{|c|}{ Amu Darya and Syr Darya basins } \\
\hline & AralMountain model & $\begin{array}{l}\text { For the Amu Darya, glacier melt and snowmelt contribute } \\
\text { to } 38 \text { and } 26.9 \% \text { of runoff, while for the Syr Darya the pro- } \\
\text { portions are } 10.7 \text { and } 35.2 \% \text {. }\end{array}$ & $\begin{array}{l}\text { Fully simulated the hydrological pro- } \\
\text { cesses. }\end{array}$ & Immerzeel et al. (2012a) \\
\hline & & $\begin{array}{l}\text { Glacier will retreat by } 46.4-59.5 \% \text { by } 2050 \text { depending on } \\
\text { selected GCM (General Circulation Model). For the Syr } \\
\text { Darya, average water supply to the downstream will de- } \\
\text { crease by } 15 \% \text { for } 2021-2030 \text { and } 25 \% \text { for } 2041-2050 \text {. } \\
\text { For the Amu Darya the expected decreases are } 13 \% \text { ( } 2021- \\
2030) \text { and } 31 \% \text { (2041-2050). }\end{array}$ & & \\
\hline $\begin{array}{l}\text { Test sites } \\
\text { "Abramov" in } \\
\text { SyrDarya and } \\
\text { "Oigaing"in } \\
\text { Amu Darya }\end{array}$ & $\begin{array}{l}\text { HBV-ETH (HBV model ex- } \\
\text { panded at the Swiss Federal } \\
\text { Institute of Technology) and } \\
\text { OEZ (a water balance equa- } \\
\text { tion model) }\end{array}$ & $\begin{array}{l}\text { Overall good model performances were achieved with the } \\
\text { maximum discrepancy of simulated and observed monthly } \\
\text { runoff within } 20 \mathrm{~mm} \text {. } \\
\text { General enhanced snowmelt during spring and a higher } \\
\text { flood risk in summer are predicted under a doubling atmo- } \\
\text { spheric } \mathrm{CO}_{2} \text { concentration with greatest runoff increases } \\
\text { occurring in August for the highly glaciated catchments and } \\
\text { in June for the nival catchment. }\end{array}$ & $\begin{array}{l}\text { It considered geographical, topographi- } \\
\text { cal and hydrometeorological features of } \\
\text { test sites, and reduced modeling uncer- } \\
\text { tainties. } \\
\text { This procedure requires a lot meteoro- } \\
\text { logical and land surface data and knowl- } \\
\text { edge of the hydrological processes. }\end{array}$ & Hagg et al. (2007) \\
\hline Panj River & HBV-ETH & $\begin{array}{l}\text { For the upper Panj catchment, the current glacier extent will } \\
\text { decrease by } 36 \text { and } 45 \% \text {, respectively, assuming tempera- } \\
\text { ture increment being } 2.2 \text { and } 3.1^{\circ} \mathrm{C} \text {. }\end{array}$ & $\begin{array}{l}\text { Application of glacier parameterization } \\
\text { scheme. }\end{array}$ & Hagg et al. (2013) \\
\hline Naryn River & SWAT-RSG model & $\begin{array}{l}\text { Glacier area has decreased } 7.3 \% \text { during 1973-2002. } \\
\text { Glaciers will recede with only } 8 \% \text { of the small glaciers re- } \\
\text { tain by } 2100 \text { under RCP } 8.5 \text { and net glacier melt runoff will } \\
\text { reach peak in about } 2040 \text { and decrease later. }\end{array}$ & $\begin{array}{l}\text { Incorporated glacier dynamics and vali- } \\
\text { dated the model using two glacier inven- } \\
\text { tories. }\end{array}$ & Gan et al. (2015) \\
\hline Syr Darya & $\begin{array}{l}\text { NAM model with a separate } \\
\text { land-ice model }\end{array}$ & $\begin{array}{l}\text { Glacier volume will lose } 31 \% \pm 4 \% \text { under SRES A2 until } \\
2050 \text { s, and the runoff peak will shift forward by } 30-60 \text { days } \\
\text { from the current spring/early summer towards a late win- } \\
\text { ter/early spring runoff regime. }\end{array}$ & $\begin{array}{l}\text { The NAM model was improved to be ro- } \\
\text { bust using only five freely calibrated pa- } \\
\text { rameters. }\end{array}$ & Siegfried et al. (2012) \\
\hline
\end{tabular}

model was used to calculate the components of runoff in the source river for the Tarim River. The results showed that, in terms of runoff, glacier meltwater, snowmelt water and rainfall accounted for $43.8,27.7$ and $28.5 \%$ of the Kumalike River, and 23.0, 26.1 and $50.9 \%$ of the Toxkan River, respectively (Zhao et al., 2013); this result is comparable to the conclusion that glacier melt accounts for $31-36 \%$ based on isotope tracer (Sun et al., 2016). However, accurately quantifying the contributions of glacier melt, snowmelt and rainfall to runoff in central Asian streams is challenging (UngerShayesteh et al., 2013).

\subsection{Glacio-hydrological responses to climate change: a comparison}

To analyze the hydrological responses to climate change of the glacierized Tienshan Mountains, the responses of several major glacierized mountainous regions are discussed. For the Himalaya-Hindu Kush region, investigations suggested that a regression of the maximum spring streamflow period in the annual cycle of about 30 days, and annual runoff decreased by about $18 \%$ for the snow-fed basin, whereas it increased by about $33 \%$ for the glacier-fed basin using the Satluj Basin as a typical region (Singh and Bengtsson, 2005). For the Tibetan Plateau, the glacier retreat could lead to an expansion of lakes; e.g., glacier mass loss between 1999 and 2010 con- tributed to about $11.4-28.7 \%$ of the lake level rise in the three glacier-fed lakes, namely, Siling Co, Nam Co and Pung Co (Lei et al., 2013). Analysis from groundwater storage indicated that the groundwater for the major basins in the Tibetan Plateau increased during 2003-2009 with a trend rate of $+1.86 \pm 1.69 \mathrm{Gt} \mathrm{yr}^{-1}$ for the Yangtze River Source Region and $+1.14 \pm 1.39 \mathrm{Gt} \mathrm{yr}^{-1}$ for the Yellow River Source Region (Xiang et al., 2016).

For the South American Andes, melting at the glacier summit has occurred. With the continually increase in temperature, although glacier melt was dominated by maybe other processes in some regions, the probability seems high that the current glacier melting will continue. With the loss of glacier water, the current dry-season water resources will be heavily depleted once the glaciers have disappeared (Barnett et al., 2005).

For the Alps, many investigations have been implemented, ranging from glacier-scale modeling to large basinscale or region-scale modeling (Finger et al., 2015; Abbaspour et al., 2015). Glacier meltwater provided about $5.28 \pm 0.48 \mathrm{~km}^{3} \mathrm{a}^{-1}$ of freshwater during 1980-2009. About $75 \%$ of this volume occurred during July-September, providing water for large low-lying rivers including the Po, the Rhine and the Rhône (Farinotti et al., 2016). Under the context of climate change, decreases of glacier meltwater in both annual and summer runoff contributions are anticipated. For 
example, annual runoff contributions from presently glacierized surfaces are expected to decrease by $13 \%$ by $2070-2099$ compared to 1980-2009, despite of nearly unchanged contributions from precipitation under RCP 4.5 (Farinotti et al., 2016).

The hydrological processes in the glacierized regions have something in common; i.e., the annual runoff is likely to reduce in a warming climate with high spatial-temporal variation at the middle or end of the 21st century. Seasonally, increased snowmelt runoff and water shortage of summer runoff with the disappearing glaciers are expected. However, there are also differences in the responses of hydrological processes to climate change. For example, the contrasting climate change impact on river flows from glacierized catchments in the Himalayas and Andes (Ragettli et al., 2016). In the Langtang catchment in Nepal, increased runoff is expected with limited shifts between seasons, whereas for the Juncal catchment in Chile, the runoff has already been decreasing. These qualitative or quantitative differences are mainly caused by glaciation ratio, regional weather pattern and glacier property (Hagg and Braun, 2005).

However, for many glacierized catchment in the Tienshan Mountains, currently or for the next several decades, the runoff appears to be normal or even an increasing trend, giving an illusion of better prospects. It is particularly worth mentioning that, once the glacier storage (fossil water) melts away, the water system is likely to go from plenty to want, exacerbating water stress given the increasing water demand.

\section{Limitations of the available hydrological models}

\subsection{Meteorological inputs in hydrological modeling and prediction}

In mountainous regions of central Asia, meteorological input uncertainty could account for over $60 \%$ of model uncertainty (Fang et al., 2015a). The greatest challenge in hydrological modeling has been lack of robust and reliable complete meteorological data, especially since the collapse of the Soviet Union in the late 1980s. In this section, the value and limitations of different data sets used in hydrological modeling (e.g., station data, remote sensing data) and future predictions (e.g., outputs of GCMs (General Circulation Models) and RCMs (Regional Climate Models) are discussed.

\subsubsection{Observational data}

Traditionally, hydrological models are forced by stationscale meteorological data in or near the studied watershed (e.g., Fang et al., 2015a; Peng and Xu, 2010). However, station-scale data can only describe the climate at a specific point in space, and most of them located at the foot of mountains. This limitation needs to be taken into consideration when interpolating station data into basin-scale over rugged terrain. Li et al. (2014) applied the interpolated gridded pre- cipitation data set (APPRODITE) to force the SRM model. Applying in situ observational meteorological data is also associated with other challenges, as detailed below.

\section{Lack of stations}

One of the greatest challenges inherent in station-scale meteorological data is the low density of meteorological stations. As the mountainous regions of central Asia are characterized by complex terrain, it is inaccurate to represent the climatic conditions of basins using data from limited stations. Some researchers (Liu et al., 2016b; Fang et al., 2015a) have addressed this challenge by attempting to interpolate temperature/precipitation into a basin scale using elevation bands, based on the assumption that climate variables increase or decrease with elevation. Temperature lapse rates could also be validated using the Integrated Global Radiosonde Archive (IGRA) data set (Li and Williams, 2008). However, this modification could not take account of the source of water vapor and mountain aspect for basins with complex landform. Due to the fact that uniform precipitation gradients cannot be derived and temperature lapse rates are not constant throughout the year (Immerzeel et al., 2014), it is a challenge to use elevation bands to interpolate station-scale climate into basinscale climate.

\section{Lack of homogeneity test}

Many hydrological modeling studies do not factor in errors in observations, even though homogeneous climate records are required in hydrological design. In central Asia, changes in regulation protocols or relocation of stations also lead to observational errors. Checking the input data should be the first step in hydrological modeling due to the rule of "garbage in yields garbage out".

\subsubsection{Remote sensing data and reanalysis data}

Remote sensing and reanalysis data are increasingly being used in hydrological modeling. T. Liu et al. (2012) and Liu et al. (2016b) evaluated remote sensing precipitation data of the Tropical Rainfall Measuring Mission (TRMM) and temperature data of Moderate Resolution Imaging Spectroradiometer (MODIS). The results indicated that snow storage and snowpack that were modeled using the remote sensing climate are different from those modeled using station-scale observational data. The model forced by the remote sensing data showed better performance in spring snowmelt (T. Liu et al., 2012). Huang et al. (2010a) analyzed the input uncertainty of remote sensing precipitation data interpreted from FY-2. In addition to meteorological data, surface information interpreted from satellite images, e.g., soil moisture, land use and snow cover, can also be used in hydrologic modeling (Cai et al., 2014).

As demonstrated in numerous research studies, data assimilation holds considerable potential for improving hydro- 
logical predictions (Y. Liu et al., 2012). Cai et al. (2014) used Global Land Data Assimilation System (GLDAS) $3 \mathrm{~h}$ air temperature data to force the MS-DTVGM model, while Duethmann et al. (2015) used the Watch Forcing Data based on ERA-40 (WFD-E40) to force the hydrological model.

Remote sensing and reanalysis data are supposed for use in large-scale hydrological modeling due to their low spatial resolution. Another limitation in using remote sensing and reanalysis data is that these data are biased to some extent. For example, the TRMM data are mostly valuable only for tropical regions, and reanalysis data, including ERA-40, NCEP/NCAR and GPCC (Global Precipitation Climatology Centre), fail to reveal any significant correlation with station data (Sorg et al., 2012).

Given the advantages and disadvantages of observation data, remote sensing data and reanalysis data, a better approach would be to combine observations and other data sets in hydrological modeling.

\subsubsection{GCM or RCM outputs}

GCMs or RCMs provide climate variables for evaluating future hydrological processes. However, the greatest challenges in applying these data sets are their low spatial resolutions (e.g., the spatial resolution of GCMs in CMIP5 ranges from 0.75 to $3.25^{\circ}$ ) and considerable biases. In addition, different GCMs or RCMs generally give different climate projections. Therefore, when forcing a hydrological model using the outputs of climate models, the evaluation results depend heavily on the selection of GCMs and consequently result in higher uncertainty in GCMs than that in other sources (emission scenarios, hydrological models, downscaling, etc.) (Bosshard et al., 2013).

Many downscaling methods have been developed to overcome these drawbacks. Although some statistical downscaling methods, such as SDSM (Wilby et al., 2002), are widely used in climate change impact studies, their use in the mountainous regions of central Asia is limited due to the lack of fine observational data to downscale GCM outputs. To overcome the data scarcity for this region, G. H. Fang et al. (2015) evaluated different bias correction methods in downscaling the outputs of one RCM model and used the bias-corrected climate to force a hydrological model in the data-scarce Kaidu River basin. Liu et al. (2011) used perturbation factors to downscale the GCM outputs and force the hydrological model.

\subsection{Glacier melt modeling}

Glacier melt accounts for a large part of the discharge for the alpine basins in central Asia as discussed above. However, most hydrological modeling does not include glacier melt and accumulation processes. For example, Liu et al. (2010) failed to account for the glacier processes in the VIC model in the Tarim River; Peng and Xu (2010) missed the glacier module in Xinanjiang and TOPMODEL; and Fang et al. (2015a) failed to account for glacier processes, though the glacier melt could contribute up to $10 \%$ of discharge of the Kaidu River basin. Similarly, in their research on the Yarkand River basin, Liu et al. (2016a) neglected the influence of glacier melt in the SWAT and MIKE-SHE models, even though the glacier covered an area of $5574 \mathrm{~km}^{2}$. The most widely used hydrological models, such as the distributed SWAT, the MIKE-SHE model and the conceptual SRM model, as a rule do not calculate glacier melt processes, despite the fact that excluding the glacier processes could induce large errors in glacierized catchments. Glacier processes are complex in that glacier melt will at first increase due to the rise in ablation and lowering of glacier elevation, and then, after reaching its peak, will decrease due to the shrinking in glacier area (Xie et al., 2006). Moreover, simulation errors can be re-categorized as precipitation or glacier meltwater and consequently result in a greater uncertainty in the water balance in high mountain areas (Mayr et al., 2013).

During the last few decades, a large variety of melt models have been developed (Hock, 2005). Previous studies have investigated glacier dynamics for the mountainous regions. Among these studies, Hock (2005) reviewed glacier meltrelated processes at the surface-atmosphere interface ranging from a simple temperature-index model to a sophisticated energy-balance model. Glacier models that are physically based (e.g., mass-energy fluxes and glacier flow dynamics) depend heavily on detailed knowledge of local topography and hydrometeorological data, which are generally limited in high mountain regions (Michlmayr et al., 2008). Hence, they mostly applied to well-documented glaciers and have few applications in basin-scale hydrological models.

The temperature-index method (or its variants), which only requires temperature for meteorological input, is widely used to calculate glacier melt (Konz and Seibert, 2010). As is illustrated by Oerlemans and Reichert (2000), glaciers can be reconstructed from long-term meteorological records, e.g., summer temperature is the dominant factor for glaciers in a dry climate (e.g., Abramov glacier). In recent years, hydrologists have been trying to add other meteorological variables into the calculations of glacier melt; e.g., Y. Zhang et al. (2007) included potential clear sky direct solar radiation in the degree-day model, and Yu et al. (2013) stated that accumulated temperature is more effective than daily average temperature for calculating the snowmelt runoff model. Using degree-day calculation is much simpler than using energy balance approaches and could actually produce comparable or better model performance when applied in mountainous basins (Ohmura, 2001).

More recently, the melt module has been incorporated into different kinds of hydrological models. Zhao et al. (2015) integrated a degree-day glacier melt algorithm into a macroscale hydrologic model (VIC) and indicated that annual and summer runoff would decrease by 9.3 and $10.4 \%$, respectively, for reductions in glacier areas of $13.2 \%$ in the 
Kumalike River basin. Hagg et al. (2013) analyzed anticipated glacier and runoff changes in the Rukhk catchment of the upper Amu Darya Basin, using the HBV-ETH model by including glacier melt and snowmelt processes. Their results showed that with temperature increases of 2.2 and $3.1^{\circ} \mathrm{C}$, the current glacier extent of $431 \mathrm{~km}^{2}$ will reduce by 36 and $45 \%$, respectively. Luo et al. (2013), taking the Manas River basin as a case study, investigated glacier melt processes by including the algorithm of glacier melt, sublimation/evaporation, accumulation, mass balance and retreat in a SWAT model. The results showed that glacier melt contributed $25 \%$ to streamflow, although the glacier area makes up only $14 \%$ of the catchment drainage area.

\subsubsection{Paucity of glacier variation data}

The existing glacier data set, which includes the World Glacier Inventory (WGI), the Randolph Glacier Inventory (RGI) and global land-ice measurements from space (GLIMS), has been developed rapidly. These data, however, generally focus on glaciers in the present time or those existing in the former Soviet Union. For example, the source data of WGI were derived during 1940s-1960s, and the GLIMS for the Amu Darya Basin is from 1960 to 2004 (Donald et al., 2015). These data can depict the characteristics of the glacier status, but fail to reproduce glacier variation. Only a few glaciers (Abramov, Tuyuksu, Urumqi no. 1 Glacier, etc.) have long-term variation measurements (Savoskul and Smakhtin, 2013). CAWa (Central Asian Water; www.cawa-project.net/) are intended to contribute to a reliable regional data basis of central Asia from the monitoring stations, sampling and remote sensing. The missing glacier variation information leads to a misrepresentation of glacier dynamics.

\subsubsection{Lack of glacier mass balance data}

Glacier measurements reproduced by remote sensing data usually give glacier area instead of glacier water equivalent; therefore, errors will occur when converting glacier area to glacier mass. Glaciologists normally use a specified relation (e.g., empirical) between glacier volume and glacier area to estimate glacier mass balance (Stahl et al., 2008; Luo et al., 2013). Aizen et al. (2007) applied the radio-echo sounding approach to obtain glacier ice volume. Recently, ICESat (Ice, Cloud and land Elevation Satellite; http://icesat.gsfc.nasa.gov/) could provide multi-year elevation data needed to determine ice-sheet mass balance.

This paper focuses primarily on glacier melt modules. It does not discuss snowmelt processes, as hydrological models generally include them either in a degree-day approach or energy balance basis. Furthermore, this paper does not analyze water routing processes or evapotranspiration because there are several ways to simulate soil water storage change and model evapotranspiration (Bierkens, 2015).

\subsection{Model calibration and validation}

For model calibration, two important issues are discussed here: the length of the calibration period and objective functions.

Generally, hydrological modeling requires several years' calibration. For example, Yang et al. (2012) indicated that a 5 -year warm-up is sufficient before hydrological model calibration and a 4-year calibration could obtain satisfactory model performance. More venturesomely, a 6-month calibration could lead to good model performance for an arid watershed (Sun et al., 2016). Konz and Seibert (2010) stated that one year's calibration of using glacier mass balances could effectively improve the hydrological model. Selecting the appropriate calibration period is significant, as model performance could depend on calibration data. Refsgaard (1997) used a split-sample procedure to obtain better model calibration and validation effectively and efficiently.

Most studies on calibration procedures in hydrology have examined goodness-of-fit measures based on simulated and observed runoff. However, as the hydrological sciences develop further, multi-objective calibration is emerging as the preferred approach. It not only includes multi-site streamflow (which has proved to be advantageous compared to singlesite calibration (S. Wang et al., 2012), and multi-metrics of streamflow (Yang et al., 2014), but also involves multiple examined hydrological components (e.g., soil moisture). Most of the studies reviewed here use the discharge to calibrate and validate the hydrological model, yet Gupta et al. (1998) argued that a strong "equifinality effect" may exist due to the compensation effect, where an underestimation of precipitation may be compensated by an overestimation of glacier melt, and vice versa. Stahl et al. (2008) suggested that observations on mass balances should be used for model calibration, as large uncertainties exist in the data-scarce alpine regions. Therefore, multi-criteria calibration and validation is necessary, especially for glacier/snow recharged regions.

Many recent studies have attempted to include mass balance data into model calibration (Stahl et al., 2008; Huss et al., 2008; Konz and Seibert, 2010; Parajuli et al., 2009). Duethmann et al. (2015) used a multi-objective optimization algorithm that included objective functions of glacier mass balance and discharge to calibrate the hydrological model WASA (Model of Water Availability in Semi-Arid Environments). Another approach for improving model efficiency is to calibrate the glacier melt processes and the precipitation dominated processes separately (Immerzeel et al., 2012b). Further, in addition to the mass balance data used to calibrate the hydrological model, the glacier-area/glacier-volume scaling factor can also be calibrated with the observed glacier area change monitored by remote sensing data (Zhang et al., 2012b). 


\section{Future challenges and directions}

Modeling hydrological processes and understanding hydrological changes in mountainous river basins will provide important insights into future water availability for downstream regions of the basins. In modeling the glacierized catchments of central Asia, the greatest challenge still remains the lack of reliable and complete data, including meteorological data, glacier data and surface conditions. This challenge is very difficult to overcome due to the inaccessibility of the terrain and the oftentimes conflicting politics of the countries that share the region. Even so, future efforts could be focused on constructing additional stations and doing more observations (e.g., the AKSU-TARIM project; http://www.aksu-tarim.de/).

For alpine basins with scarce data, knowledge about water generation processes and the future impact of climate change on water availability is also poor. Moreover, the contribution of glacier melt varies significantly among basins and even along river channels, adding even more complexity to hydrological responses to climate change.

Uncertainty should always be analyzed and calculated in hydrological modeling, especially when evaluating climate change impact studies that contain a cascade of climate models, downscaling, bias correction and hydrological modeling, whose uncertainties are currently insufficiently quantified (Johnston and Smakhtin, 2014). The evaluation contains uncertainty in each part of the cascade, such as climate modeling uncertainty or hydrological modeling uncertainty (i.e., input uncertainty, structure or module uncertainty and parameter uncertainty), all of which could lead to a considerably wide bandwidth compared to the changes of the water resources. In contrast, by taking into account all of these uncertainties, reliable evaluation of model confidence could be acquired by decision-makers and peers.

\subsection{Publication of model setups and input data}

As was suggested by Johnston and Smakhtin (2014), publication of model setups and input data is necessary for other researchers to replicate the modeling or build coherent nested models. From these setups and data, researchers can build their own models from existing work rather than starting from scratch. Another advantage of researchers sharing their work is to help each other evaluate existing models from other viewpoints.

\subsection{Integration of different data sources}

After appropriate preprocessing, several types of data, including remote sensing and reanalysis, could be used in hydrological modeling, as Liu et al. (2013) indicated that remote sensing data could reproduce comparable results to the traditional station data. In recent years, isotope data are increasingly used to define water components (Sun et al., 2016) and it would be a fortune for hydrologists to validate their models, or even calibrate the models (Fekete et al., 2006). The overall idea here is to build and integrate more comprehensive data sets in order to improve hydrological modeling. An example of this approach can be found in Naegeli et al. (2013), who attempted to construct a worldwide data set of glacier thickness observations compiled entirely from a literature review.

\subsection{Multi-objective calibration and validation}

A hydrological model should not only "mimic" observed discharge but also well reproduce snow accumulation and melt dynamics or the glacier mass change (e.g., Konz and Seibert, 2010). As discussed previously, hydrological models that are calibrated based on discharge alone may be of high uncertainty and even "equifinality" for different parameters or inputs. This could happen especially when one or several modules are missing. For example, one might overestimate the mountainous precipitation or underestimate the evapotranspiration if the glacier melt module is missing. Therefore, it is suggested to account for each hydrological component as much as possible. We strongly suggest the use of multiobjective functions and multi-metrics to calibrate and evaluate hydrological models. Compared to single objective calibration, which was dependent on the initial starting location, multi-objective calibration provides more insight into parameter sensitivity and helps to understand the conflicting characteristics of these objective functions (Yang et al., 2014). Therefore, the use of different kinds of data and objective functions could improve a hydrological model and provide more realistic results.

For the data-scarce Tienshan Mountains, however, we do not recommend an overcomplex or physicalized modeling of each component as lack of validation data, which may result in equifinality discussed previously under stable climate. The more empirical models (enhanced temperature-index approaches) could reproduce comparable results to the sophisticated, fully physically based models (Hock, 2005). It is worth mentioning that the physically based glacier models are more advanced when quantify future dynamics of glaciers and glacier/snow redistribution when the climatic and hydrologic systems are not stable (Hock, 2005). The physical models should be further developed and used in glacier modeling as long as there is enough input and validation data.

Having a reliable hydrological model is important for understanding and modeling water changes, which are key issues of water resources management. The developments and associated challenges described in this paper are extrapolations of current trends and are likely to be the focus of research in the coming decades. 


\section{Data availability}

As a review article, this paper does not include any research data. All the cited references could be found through the Internet.

Author contributions. Yaning Chen and Weihong Li wrote the main manuscript text; Gonghuan Fang and Zhi Li prepared Fig. 1 and gave some assistance to paper searching and reviewing. All authors reviewed the manuscript.

Acknowledgements. The research is supported by the National Natural Science Foundation of China (41630859; 41471030) and the CAS "Light of West China" Program (2015-XBQN-B-17).

Edited by: Q. Chen

Reviewed by: Y. Zhang and one anonymous referee

\section{References}

Abbaspour, K. C., Rouholahnejad, E., Vaghefi, S., Srinivasan, R., Yang, H., and Kløve, B.: A continental-scale hydrology and water quality model for Europe: Calibration and uncertainty of a high-resolution large-scale SWAT model, J. Hydrol., 524, 733752, doi:10.1016/j.jhydrol.2015.03.027, 2015.

Aerts, J., Renssen, H., Ward, P., De Moel, H., Odada, E., Bouwer, L., and Goosse, H.: Sensitivity of global river discharges under Holocene and future climate conditions, Geophys. Res. Lett., 33, L19401, doi:10.1029/2006GL027493, 2006.

Aizen, V., Aizen, E., and Kuzmichonok, V.: Glaciers and hydrological changes in the Tien Shan: simulation and prediction, Environ. Res. Lett., 2, 045019, doi:10.1088/1748-9326/2/4/045019, 2007.

Aizen, V. B., Aizen, E. M., Melack, J. M., and Dozier, J.: Climatic and hydrologic changes in the Tien Shan, central Asia, J. Climate, 10, 1393-1404, 1997.

Barnett, T. P., Adam, J. C., and Lettenmaier, D. P.: Potential impacts of a warming climate on water availability in snow-dominated regions, Nature, 438, 303-309, 2005.

Bierkens, M. F. P.: Global hydrology 2015: State, trends, and directions, Water Resour. Res., 51, 4923-4947, doi:10.1002/2015WR017173, 2015.

Bosshard, T., Carambia, M., Goergen, K., Kotlarski, S., Krahe, P., Zappa, M., and Schär, C.: Quantifying uncertainty sources in an ensemble of hydrological climate-impact projections, Water Resour. Res., 49, 1523-1536, doi:10.1029/2011WR011533, 2013.

Cai, M., Yang, S., Zeng, H., Zhao, C., and Wang, S.: A distributed hydrological model driven by multi-source spatial data and its application in the Ili River Basin of Central Asia, Water Resour. Manag., 28, 2851-2866, 2014.

Chen, R., Qing, W., Liu, S., Han, H., He, X., Wang, J., and Liu, G.: The relationship between runoff and ground temperature in glacierized catchments in China, Environ. Earth Sci., 65, 681687, 2012.

Chen, Y.: Water resources research in Northwest China, Springer Science \& Business Media, doi:10.1007/978-94-017-8017-9, 2014.
Chen, Y., Takeuchi, K., Xu, C. C., Chen, Y. P., and Xu, Z. $\mathrm{X}$.: Regional climate change and its effects on river runoff in the Tarim Basin, China, Hydrol. Process, 20, 2207-2216, doi:10.1002/hyp.6200, 2006.

Chen, Y., Li, Z., Fan, Y., Wang, H., and Deng, H.: Progress and prospects of climate change impacts on hydrology in the arid region of northwest China, Environ. Res., 139, 11-19, 2015.

Dikich, A. and Hagg, W.: ABHANDLUNGEN-Climate driven changes of glacier runoff in the Issyk-Kul Basin, Kyrgyzstan, Zeitschrift fur Gletscherkunde und Glazialgeologie, 39, 75-86, 2003 (in Russian).

Donald, A., Ulrich, K., and Caleb, P.: The Role of Glaciers in the Hydrologic Regime of the Amu Darya and Syr Darya Basins, Washington, D.C., 2015.

Dong, W., Cui, B., Liu, Z., and Zhang, K.: Relative effects of human activities and climate change on the river runoff in an arid basin in northwest China, Hydrol. Process., 28, 4854-4864, 2014.

Duethmann, D., Bolch, T., Farinotti, D., Kriegel, D., Vorogushyn, S., Merz, B., Pieczonka, T., Jiang, T., Su, B. D., and Guntner, A.: Attribution of streamflow trends in snow and glacier meltdominated catchments of the Tarim River, Central Asia, Water Resour. Res., 51, 4727-4750, doi:10.1002/2014wr016716, 2015.

Fan, J., Jiang, Y., Chen, Y., Chen, P., Bai, S., and Yu, X.: The Critical Rainfall Calculation in Kaidu River Based on HBV Hydrological Model, Desert and Oasis Meteorology, 8, 31-35, 2014.

Farinotti, D., Longuevergne, L., Moholdt, G., Duethmann, D., Mölg, T., Bolch, T., Vorogushyn, S., and Güntner, A.: Substantial glacier mass loss in the Tien Shan over the past 50 years, Nat. Geosci., 8, 716-722, doi:10.1038/ngeo2513, 2015.

Farinotti, D., Pistocchi, A., and Huss, M.: From dwindling ice to headwater lakes: could dams replace glaciers in the European Alps?, Environ. Res. Lett., 11, 054022, doi:10.1038/NGEO2513, 2016.

Fang, G., Yang, J., Chen, Y., Xu, C., and De Maeyer, P.: Contribution of meteorological input in calibrating a distributed hydrologic model in a watershed in the Tianshan Mountains, China, Environ. Earth Sci., 74, 2413-2424, doi:10.1007/s12665-0154244-7, 2015a.

Fang, G., Yang, J., Chen, Y., Zhang, S., Deng, H., Liu, H., and De Maeyer, P.: Climate Change Impact on the Hydrology of a Typical Watershed in the Tianshan Mountains, Advances in Meteorology, 2015, 1-10, doi:10.1155/2015/960471, 2015b.

Fang, G. H., Yang, J., Chen, Y. N., and Zammit, C.: Comparing bias correction methods in downscaling meteorological variables for a hydrologic impact study in an arid area in China, Hydrol. Earth Syst. Sci., 19, 2547-2559, doi:10.5194/hess-19-25472015, 2015.

Fekete, B. M., Gibson, J. J., Aggarwal, P., and Vörösmarty, C. J.: Application of isotope tracers in continental scale hydrological modeling, J. Hydrol., 330, 444-456, doi:10.1016/j.jhydrol.2006.04.029, 2006.

Finger, D., Vis, M., Huss, M., and Seibert, J.: The value of multiple data set calibration versus model complexity for improving the performance of hydrological models in mountain catchments, Water Resour. Res., 51, 1939-1958, 2015.

Gan, R. and Luo, Y.: Using the nonlinear aquifer storage-discharge relationship to simulate the base flow of glacier- and snowmeltdominated basins in northwest China, Hydrol. Earth Syst. Sci., 17, 3577-3586, doi:10.5194/hess-17-3577-2013, 2013. 
Gan, R., Luo, Y., Zuo, Q. T., and Sun, L.: Effects of projected climate change on the glacier and runoff generation in the Naryn River Basin, Central Asia, J. Hydrol., 523, 240-251, doi:10.1016/j.jhydrol.2015.01.057, 2015.

Guo, L., Xia, Z., and Wang, Z.: Comparisons of hydrological variations and environmental effects between Aral Sea and Lake Balkhash, Adv. Water Sci., 22, 764-770, 2011.

Guo, L., Xia, Z., Zhou, H., Huang, F., and Yan, B.: Hydrological Changes of the Ili River in Kazakhstan and the Possible Causes, J. Hydraul. Eng.-ASCE, 20, 05015006, doi:10.1061/(asce)he.1943-5584.0001214, 2015.

Gupta, H. V., Sorooshian, S., and Yapo, P. O.: Toward improved calibration of hydrologic models: Multiple and noncommensurable measures of information, Water Resour. Res., 34, 751-763, 1998.

Hagg, W. and Braun, L.: The influence of glacier retreat on water yield from high mountain areas: comparison of Alps and Central Asia, Climate and Hydrology in Mountain Areas, 18, 263-275, 2005.

Hagg, W., Braun, L., Weber, M., and Becht, M.: Runoff modelling in glacierized Central Asian catchments for present-day and future climate, Nordic Hydrology, 37, 93-105, 2006.

Hagg, W., Braun, L. N., Kuhn, M., and Nesgaard, T. I.: Modelling of hydrological response to climate change in glacierized Central Asian catchments, J. Hydrol., 332, 40-53, doi:10.1016/j.jhydrol.2006.06.021, 2007.

Hagg, W., Hoelzle, M., Wagner, S., Mayr, E., and Klose, Z.: Glacier and runoff changes in the Rukhk catchment, upper AmuDarya basin until 2050, Global Planet. Change, 110, 62-73, doi:10.1016/j.gloplacha.2013.05.005, 2013.

Hock, R.: Glacier melt: a review of processes and their modelling, Prog. Phys. Geog., 29, 362-391, 2005.

Huai, B., Li, Z., Sun, M., and Xiao, Y.: Snowmelt runoff model applied in the headwaters region of Urumqi River, Arid Land Geography, 36, 41-48, 2013 (in Chinese with English abstract).

Huang, S., Krysanova, V., Zhai, J., and Su, B.: Impact of Intensive Irrigation Activities on River Discharge Under Agricultural Scenarios in the Semi-Arid Aksu River Basin, Northwest China, Water Resour. Manag., 29, 945-959, doi:10.1007/s11269-0140853-2, 2015.

Huang, Y., Chen, X., Bao, A., and Ma, Y.: Distributed Hydrological Modeling in Kaidu Basin: MIKE-SHE Model Calibration and Uncertainty Estimation, J. Glaciol. Geocryol., 32, 567-572, 2010a (in Chinese with English abstract).

Huss, M., Farinotti, D., Bauder, A., and Funk, M.: Modelling runoff from highly glacierized alpine drainage basins in a changing climate, Hydrol. Process., 22, 3888-3902, doi:10.1002/hyp.7055, 2008.

Ibatullin, S., Yasinsky, V., and Mironenkov, A.: Impacts of climate change on water resources in Central Asia, Sector report no. 6, Eurasian development bank, Almaty, 44 pp., 2009.

Immerzeel, W. W., Van Beek, L. P., and Bierkens, M. F.: Climate change will affect the Asian water towers, Science, 328, 1382$1385,2010$.

Immerzeel, W. W., Lutz, A., and Droogers, P.: Climate change impacts on the upstream water resources of the Amu and Syr Darya River basins, Wageningen, the Netherlands, 1-103, 2012a.

Immerzeel, W. W., Van Beek, L., Konz, M., Shrestha, A., and Bierkens, M.: Hydrological response to climate change in a glacierized catchment in the Himalayas, Climatic Change, 110, 721-736, 2012b.

Immerzeel, W. W., Petersen, L., Ragettli, S., and Pellicciotti, F.: The importance of observed gradients of air temperature and precipitation for modeling runoff from a glacierized watershed in the Nepalese Himalayas, Water Resour. Res., 50, 2212-2226, doi:10.1002/2013WR014506, 2014.

Johnston, R. and Smakhtin, V.: Hydrological Modeling of Large river Basins: How Much is Enough?, Water Resour. Manag., 28, 2695-2730, doi:10.1007/s11269-014-0637-8, 2014.

Kaldybayev, A., Chen, Y., Issanova, G., Wang, H., and Mahmudova, L.: Runoff response to the glacier shrinkage in the Karatal river basin, Kazakhstan, Arabian Journal of Geosciences, 9, 1-8, doi:10.1007/s12517-015-2106-y, 2016.

Kaser, G., Großhauser, M., and Marzeion, B.: Contribution potential of glaciers to water availability in different climate regimes, $\mathrm{P}$. Natl. Acad. Sci. USA, 107, 20223-20227, 2010.

Kemmerikh, A. O.: The role of glaciers for river runoff in Central Asia [Rol' lednikov v stoke rek Sredney Azii], Data of Glaciological Studies, 20, 82-94, 1972 (in Russian).

Kezer, K. and Matsuyama, H.: Decrease of river runoff in the Lake Balkhash basin in Central Asia, Hydrol. Process., 20, 14071423, doi:10.1002/hyp.6097, 2006.

Khan, V. and Holko, L.: Snow cover characteristics in the Aral Sea Basin from different data sources and their relation with river runoff, J. Marine Syst., 76, 254-262, 2009.

Kong, Y. and Pang, Z.: Evaluating the sensitivity of glacier rivers to climate change based on hydrograph separation of discharge, J. Hydrol., 434, 121-129, 2012.

Konz, M. and Seibert, J.: On the value of glacier mass balances for hydrological model calibration, J. Hydrol., 385, 238-246, doi:10.1016/j.jhydrol.2010.02.025, 2010.

Lei, Y., Yao, T., Bird, B. W., Yang, K., Zhai, J., and Sheng, Y.: Coherent lake growth on the central Tibetan Plateau since the 1970s: Characterization and attribution, J. Hydrol., 483, 61-67, doi:10.1016/j.jhydrol.2013.01.003, 2013.

Li, L. and Simonovic, S.: System dynamics model for predicting floods from snowmelt in North American prairie watersheds, Hydrol. Process., 16, 2645-2666, 2002.

Li, L., Shang, M., Zhang, M., Ahmad, S., and Huang, Y.: Snowmelt runoff simulation driven by APHRODITE precipitation dataset, Adv. Water Sci., 25, 53-59, 2014 (in Chinese with English abstract).

Li, X. and Williams, M. W.: Snowmelt runoff modelling in an arid mountain watershed, Tarim Basin, China, Hydrol. Process., 22, 3931-3940, 2008.

Li, Z., Wang, W., Zhang M., Wang F., and Li, H.: Observed changes in streamflow at the headwaters of the Urumqi River, eastern Tianshan, central Asia, Hydrol. Process., 24, 217-224, doi:10.1002/hyp.7431, 2010.

Liu, J., Liu, T., Bao, A., De Maeyer, P., Feng, X., Miller, S. N., and Chen, X.: Assessment of Different Modelling Studies on the Spatial Hydrological Processes in an Arid Alpine Catchment, Water Resour. Manag., 30, 1757-1770, 2016 .

Liu, J., Liu, T., Bao, A., De Maeyer, P., Kurban, A., and Chen, X.: Response of Hydrological Processes to Input Data in High Alpine Catchment: An Assessment of the Yarkant River basin in China, Water, 8, 181, doi:10.3390/w8050181, 2016 b. 
Liu, T., Willems, P., Pan, X. L., Bao, An. M., Chen, X., Veroustraete, F., and Dong, Q. H.: Climate change impact on water resource extremes in a headwater region of the Tarim basin in China, Hydrol. Earth Syst. Sci., 15, 3511-3527, doi:10.5194/hess-15-35112011, 2011.

Liu, T., Willems, P., Feng, X. W., Li, Q., Huang, Y., Bao, A. M., Chen, X., Veroustraete, F., and Dong, Q. H.: On the usefulness of remote sensing input data for spatially distributed hydrological modelling: case of the Tarim River basin in China, Hydrol. Process., 26, 335-344, doi:10.1002/hyp.8129, 2012.

Liu, Y., Weerts, A. H., Clark, M., Hendricks Franssen, H.-J., Kumar, S., Moradkhani, H., Seo, D.-J., Schwanenberg, D., Smith, P., van Dijk, A. I. J. M., van Velzen, N., He, M., Lee, H., Noh, S. J., Rakovec, O., and Restrepo, P.: Advancing data assimilation in operational hydrologic forecasting: progresses, challenges, and emerging opportunities, Hydrol. Earth Syst. Sci., 16, 3863-3887, doi:10.5194/hess-16-3863-2012, 2012.

Liu, T., Fang, H., Willems, P., Bao, A. M., Chen, X., Veroustraete, F., and Dong, Q. H.: On the relationship between historical landuse change and water availability: the case of the lower Tarim River region in northwestern China, Hydrol. Process., 27, 251261, doi:10.1002/hyp.9223, 2013.

Liu, Z., Xu, Z., Huang, J., Charles, S. P., and Fu, G.: Impacts of climate change on hydrological processes in the headwater catchment of the Tarim River basin, China, Hydrol. Process., 24, 196208, doi:10.1002/hyp.7493, 2010.

Luo, Y., Arnold, J., Allen, P., and Chen, X.: Baseflow simulation using SWAT model in an inland river basin in Tianshan Mountains, Northwest China, Hydrol. Earth Syst. Sci., 16, 1259-1267, doi:10.5194/hess-16-1259-2012, 2012.

Luo, Y., Arnold, J., Liu, S., Wang, X., and Chen, X.: Inclusion of glacier processes for distributed hydrological modeling at basin scale with application to a watershed in Tianshan Mountains, northwest China, J. Hydrol., 477, 72-85, doi:10.1016/j.jhydrol.2012.11.005, 2013.

Lutz, A., Immerzeel, W., Shrestha, A., and Bierkens, M.: Consistent increase in High Asia's runoff due to increasing glacier melt and precipitation, Nature Climate Change, 4, 587-592, 2014.

Ma, H. and Cheng, G.: A test of Snowmelt Runoff Model (SRM) for the Gongnaisi River basin in the western Tianshan Mountains, China, Chinese Sci. Bull., 48, 2253-2259, 2003.

Ma, C., Sun, L., Liu, S., Shao, M. A., and Luo, Y.: Impact of climate change on the streamflow in the glacierized Chu River Basin, Central Asia, Journa of Arid Land, 7, 501-513, 2015.

Ma, Y., Huang, Y., Chen, X., Li, Y., and Bao, A.: Modelling Snowmelt Runoff under Climate Change Scenarios in an Ungauged Mountainous Watershed, Northwest China, Math. Probl. Eng., 2013, 808565, doi:10.1155/2013/808565, 2013.

Mayr, E., Hagg, W., Mayer, C., and Braun, L.: Calibrating a spatially distributed conceptual hydrological model using runoff, annual mass balance and winter mass balance, J. Hydrol., 478, 4049, 2013.

Michlmayr, G., Lehning, M., Koboltschnig, G., Holzmann, H., Zappa, M., Mott, R., and Schoener, W.: Application of the Alpine 3D model for glacier mass balance and glacier runoff studies at Goldbergkees, Austria, Hydrol. Process., 22, 3941-3949, doi:10.1002/hyp.7102, 2008.

Miller, J. D., Immerzeel, W. W., and Rees, G.: Climate change impacts on glacier hydrology and river discharge in the Hindu
Kush-Himalayas: a synthesis of the scientific basis, Mt. Res. Dev., 32, 461-467, 2012.

Mou, L., Tian, F., Hu, H., and Sivapalan, M.: Extension of the Representative Elementary Watershed approach for cold regions: constitutive relationships and an application, Hydrol. Earth Syst. Sci., 12, 565-585, doi:10.5194/hess-12-565-2008, 2008.

Naegeli, K., Gärtner-Roer, I., Hagg, W., Huss, M., Machguth, H., and Zemp, M.: Worldwide dataset of glacier thickness observations compiled by literature review, EGU General Assembly Conference Abstracts, 2013, 3077, 2013.

Oerlemans, J. and Reichert, B.: Relating glacier mass balance to meteorological data by using a seasonal sensitivity characteristic, J. Glaciol., 46, 1-6, 2000.

Ohmura, A.: Physical basis for the temperature-based melt-index method, J. Appl. Meteorol., 40, 753-761, 2001.

Ouyang, R., Cheng, W., Wang, W., Jiang, Y., Zhang, Y., and Wang, Y.: Research on runoff forecast approaches to the Aksu River basin, Sci. China Ser. D, 50, 16-25, 2007.

Parajuli, P. B., Nelson, N. O., Frees, L. D., and Mankin, K. R.: Comparison of AnnAGNPS and SWAT model simulation results in USDA-CEAP agricultural watersheds in south-central Kansas, Hydrol. Process., 23, 748-763, doi:10.1002/hyp.7174, 2009.

Peng, D. Z. and Xu, Z. X.: Simulating the Impact of climate change on streamflow in the Tarim River basin by using a modified semidistributed monthly water balance model, Hydrol. Process., 24, 209-216, doi:10.1002/hyp.7485, 2010.

Ragettli, S., Immerzeel, W. W., and Pellicciotti, F.: Contrasting climate change impact on river flows from high-altitude catchments in the Himalayan and Andes Mountains, P. Natl. Acad. Sci. USA, 113, 9222-9227, 2016.

Refsgaard, J. C.: Parameterisation, calibration and validation of distributed hydrological models, J. Hydrol., 198, 69-97, doi:10.1016/s0022-1694(96)03329-x, 1997.

Savoskul, O. and Smakhtin, V.: Glacier systems and seasonal snow cover in six major Asian river basins: water storage properties under changing climate, International Water Management Institute, 2013.

Savoskul, O. S., Chevnina, E. V., Perziger, F. I., Vasilina, L. Y., Baburin, V. L., Danshin, A. I., Matyakubov, B., and Murakaev, R. R.: Water, climate, food, and environment in the Syr Darya Basin, Contribution to the project ADAPT, Adaptation strategies to changing environments, 2003.

Savoskul, O. S., Shevnina, E. V., Perziger, F., Barburin, V., and Danshin, A.: How Much Water will be Available for Irrigation in the Future? The Syr Darya Basin (Central Asia), in: Climate change in contrasting river basins: adaptation strategies for water, food and environment, edited by: Aerts, J. C. and Droogers, P., 93113, 2004.

Schaefli, B., Hingray, B., Niggli, M., and Musy, A.: A conceptual glacio-hydrological model for high mountainous catchments, Hydrol. Earth Syst. Sci., 9, 95-109, doi:10.5194/hess-9-95-2005, 2005.

Siegfried, T., Bernauer, T., Guiennet, R., Sellars, S., Robertson, A. W., Mankin, J., Bauer-Gottwein, P., and Yakovlev, A.: Will climate change exacerbate water stress in Central Asia?, Climatic Change, 112, 881-899, doi:10.1007/s10584-011-0253-z, 2012.

Singh, P. and Bengtsson, L.: Impact of warmer climate on melt and evaporation for the rainfed, snowfed and glacierfed 
basins in the Himalayan region, J. Hydrol., 300, 140-154, doi:10.1016/j.jhydrol.2004.06.005, 2005.

Sorg, A., Bolch, T., Stoffel, M., Solomina, O., and Beniston, M.: Climate change impacts on glaciers and runoff in Tien Shan (Central Asia), Nature Climate Change, 2, 725-731, 2012.

Stahl, K., Moore, R., Shea, J., Hutchinson, D., and Cannon, A.: Coupled modelling of glacier and streamflow response to future climate scenarios, Water Resour. Res., 44, W02422, doi:10.1029/2007WR005956, 2008.

Starodubtsev, V. and Truskavetskiy, S.: Desertification processes in the Ili River delta under anthropogenic pressure, Water Resour., 38, 253-256, 2011.

Sun, C. J., Chen, Y. N., Li, X. G., and Li, W. H.: Analysis on the streamflow components of the typical inland river, Northwest China, Hydrol. Sci. J., 61, 970-981, doi:10.1080/02626667.2014.1000914, 2016.

Sun, M., Li, Z., Yao, X., and Jin, S.: Rapid shrinkage and hydrological response of a typical continental glacier in the arid region of northwest China-taking Urumqi Glacier No. 1 as an example, Ecohydrol, 6, 909-916, 2013.

Sun, M., Li, Z., Yao, X., Zhang, M., and Jin, S.: Modeling the hydrological response to climate change in a glacierized high mountain region, northwest China, J. Glaciol., 61, 127-136, 2015.

Sun, W., Wang, Y., Cui, X., Yu, J., Zuo, D., and Xu, Z.: Physicallybased distributed hydrological model calibration based on a short period of streamflow data: case studies in two Chinese basins, Hydrol. Earth Syst. Sci. Discuss., doi:10.5194/hess-2016-192, in review, 2016.

Unger-Shayesteh, K., Vorogushyn, S., Farinotti, D., Gafurov, A., Duethmann, D., Mandychev, A., and Merz, B.: What do we know about past changes in the water cycle of Central Asian headwaters? A review, Global Planet. Change, 110, 4-25, 2013.

Wang, P., Jiang, H., and Mu, Z.: Simulation of runoff process in headstream of Aksu River, Journal of Water Resources and Water Engineering, 23, 51-57, 2012a (in Chinese with English abstract).

Wang, S., Zhang, Z., Sun, G., Strauss, P., Guo, J., Tang, Y., and Yao, A.: Multi-site calibration, validation, and sensitivity analysis of the MIKE SHE Model for a large watershed in northern China, Hydrol. Earth Syst. Sci., 16, 4621-4632, doi:10.5194/hess-164621-2012, 2012b.

Wilby, R. L., Dawson, C. W., and Barrow, E. M.: SDSM - a decision support tool for the assessment of regional climate change impacts, Environ. Modell. Softw., 17, 145-157, 2002.

World Meteorological Organization: Guide to Hydrological Practices, Volume II, Management of Water Resources and Application of Hydrological Practices, WMO-No. 168, 302 pp., 2009.

Wortmann, M., Krysanova, V., Kundzewicz, Z. W., Su, B., and Li, X.: Assessing the influence of the Merzbacher Lake outburst floods on discharge using the hydrological model SWIM in the Aksu headwaters, Kyrgyzstan/NW China, Hydrol. Process., 28, 6337-6350, doi:10.1002/hyp.10118, 2014.

Wu, S., Han, P., Li, Y., Xue, Y., and Zhu, Z.: Predicted Variation Tendency of the Water Resources in the Headwaters of the Tarim River, J. Glaciol. Geocryol., 26, 708-711, 2003 (in Chinese with English abstract)

Xiang, L., Wang, H., Steffen, H., Wu, P., Jia, L., Jiang, L., and Shen, Q.: Groundwater storage changes in the Tibetan Plateau and ad- jacent areas revealed from GRACE satellite gravity data, Earth Planet. Sc. Lett., 449, 228-239, 2016.

Xie, L., Long, A., Deng, M., Li, X., and Wang, J.: Study on Ecological Water Consumption in Delta of the Lower Reaches of Ili River, J. Glaciol. Geocryol., 33, 1330-1340, 2011.

Xie, Z.-C., Wang, X., Feng, Q.-H., Kang, E. S., Liu, C.-H., and Li, Q.-Y.: Modeling the response of glacier systems to climate warming in China, Ann. Glaciol., 43, 313-316, 2006.

Xing, K., Lei, X., Lei, X., and Jin, S.: Application of distributed hydrological model EsayDHM in runoff simulation of Manasi river basin, J. Water Res. Water Eng., 20-23, 2014 (in Chinese with English abstract).

Xu, B., Lu, Z., Liu, S., Li, J., Xie, J., Long, A., Yin, Z., and Zou, S.: Glacier changes and their impacts on the discharge in the past half-century in Tekes watershed, Central Asia, Phys. Chem. Earth, 89, 96-103, 2015.

Xu, J., Chen, Y., Li, W., Yang, Y., and Hong, Y.: An integrated statistical approach to identify the nonlinear trend of runoff in the Hotan River and its relation with climatic factors, Stoch. Env. Res. Risk A., 25, 223-233, 2011.

Xu, J., Chen, Y., Li, W., Nie, Q., Song, C., and Wei, C.: Integrating wavelet analysis and BPANN to simulate the annual runoff with regional climate change: a case study of Yarkand River, Northwest China, Water Resour. Manag., 28, 2523-2537, 2014.

Yang, J., Liu, Y., Yang, W., and Chen, Y.: Multi-objective sensitivity analysis of a fully distributed hydrologic model WetSpa, Water Resour. Manag., 26, 109-128, 2012.

Yang, J., Castelli, F., and Chen, Y.: Multiobjective sensitivity analysis and optimization of distributed hydrologic model MOBIDIC, Hydrol. Earth Syst. Sci., 18, 4101-4112, doi:10.5194/hess-184101-2014, 2014.

Yao, J. Q., Liu, Z. H., Yang, Q., Meng, X. Y., and Li, C. Z.: Responses of Runoff to Climate Change and Human Activities in the Ebinur Lake Catchment, Western China, Water Resour., 41, 738-747, doi:10.1134/s0097807814060220, 2014.

Yu, M., Chen, X., Li, L., Bao, A., and Paix, M. J.: Streamflow simulation by SWAT using different precipitation sources in large arid basins with scarce raingauges, Water Resour. Manag., 25, 2669-2681, 2011.

Yu, M., Chen, X., Li, L., Bao, A., and de la Paix, M. J.: Incorporating accumulated temperature and algorithm of snow cover calculation into the snowmelt runoff model, Hydrol. Process., 27, 3589-3595, doi:10.1002/hyp.9372, 2013.

Zhang, F. Y., Ahmad, S., Zhang, H. Q., Zhao, X., Feng, X. W., and Li, L. H.: Simulating low and high streamflow driven by snowmelt in an insufficiently gauged alpine basin, Stoch. Env. Res. Risk A., 30, 59-75, doi:10.1007/s00477-015-1028-2, 2016.

Zhang, Y., Luo, Y., Sun, L., Liu, S., Chen, X., and Wang, X.: Using glacier area ratio to quantify effects of melt water on runoff, J. Hydrol., 538, 269-277, 2016.

Zhang, S., Gao, X., Ye, B., Zhang, X., and Hagemann, S.: A modified monthly degree - model for evaluating glacier runoff changes in China. Part II: application, Hydrol. Process., 26, 1697-1706, 2012a.

Zhang, S., Ye, B., Liu, S., Zhang, X., and Hagemann, S.: A modified monthly degree - model for evaluating glacier runoff changes in China. Part I: model development, Hydrol. Process., 26, 16861696, 2012b. 
Zhang, Y., Liu, S., and Ding, Y.: Glacier meltwater and runoff modelling, Keqicar Baqi glacier, southwestern Tien Shan, China, J. Glaciol., 53, 91-98, 2007.

Zhang, Y. C., Li, B. L., Bao, A. M., Zhou, C., Chen, X., and Zhang, X. R.: Study on snowmelt runoff simulation in the Kaidu River basin, Sci. China Ser. D, 50, 26-35, 2007.

Zhao, Q., Liu, Z., Ye, B., Qin, Y., Wei, Z., and Fang, S.: A snowmelt runoff forecasting model coupling WRF and DHSVM, Hydrol. Earth Syst. Sci., 13, 1897-1906, doi:10.5194/hess-131897-2009, 2009.
Zhao, Q., Ye, B., Ding, Y., Zhang, S., Yi, S., Wang, J., Shangguan, D., Zhao, C., and Han, H.: Coupling a glacier melt model to the Variable Infiltration Capacity (VIC) model for hydrological modeling in north-western China, Environ. Earth Sci., 68, 87-101, 2013.

Zhao, Q. D., Zhang, S. Q., Ding, Y. J., Wang, J., Han, H. D., Xu, J. L., Zhao, C. C., Guo, W. Q., and Shangguan, D. H.: Modeling Hydrologic Response to Climate Change and Shrinking Glaciers in the Highly Glacierized Kunma Like River Catchment, Central Tian Shan, J. Hydrometeorol., 16, 2383-2402, doi:10.1175/jhmd-14-0231.1, 2015. 